\title{
The 5-hydroxytryptamine 4 Receptor Agonist-induced Actions and Enteric Neurogenesis in the Gut
}

\author{
Miyako Takaki, ${ }^{*}$ Kei Goto and Isao Kawahara \\ Department of Molecular Pathology, Nara Medical University School of Medicine, Kashihara, Nara, Japan
}

We explored a novel effect of 5-hydroxytryptamine 4 receptor $\left(5-\mathrm{HT}_{4} \mathrm{R}\right)$ agonists in vivo to reconstruct the enteric neural circuitry that mediates a fundamental distal gut reflex. The neural circuit insult was performed in guinea pigs and rats by rectal transection and anastomosis. A 5-HT 4 R-agonist, mosapride citrate (MOS) applied orally and locally at the anastomotic site for 2 weeks promoted the regeneration of the impaired neural circuit or the recovery of the distal gut reflex. MOS generated neurofilament-, 5- $\mathrm{HT}_{4} \mathrm{R}$ - and 5-bromo-2'-deoxyuridine-positive cells and formed neural network in the granulation tissue at the anastomosis. Possible neural stem cell markers increased during the same time period. These novel actions by MOS were in-

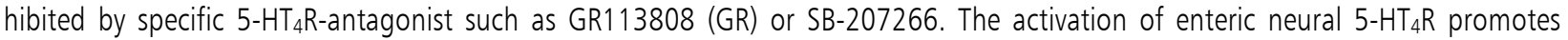
reconstruction of an enteric neural circuit that involves possibly neural stem cells. We also succeeded in forming dense enteric neural networks by MOS in a gut differentiated from mouse embryonic stem cells. GR abolished the formation of enteric neural networks. MOS up-regulated the expression of mRNA of 5-HT $\mathrm{R}_{4}$, and GR abolished this upregulation, suggesting MOS differentiated enteric neural networks, mediated via activation of $5-\mathrm{HT}_{4} \mathrm{R}$. In the small intestine in $\mathrm{H}$-line: Thy1 promoter green fluorescent protein (GFP) mice, we obtained clear 3-dimensional imaging of enteric neurons that were newly generated by oral application of MOS after gut transection and anastomosis. All findings indicate that treatment with 5 -HT R-agonists could be a novel therapy for generating new enteric neurons to rescue aganglionic disorders in the whole gut.

(J Neurogastroenterol Motil 2014;20:17-30)

Key Words

5- $\mathrm{HT}_{4}$ receptors; Enteric nervous system; Mosapride; Proto-oncogene proteins c-ret; Serotonin

Received: September 25, 2013 Revised: October 15, 2013 Accepted: October 19, 2013

(c) This is an Open Access article distributed under the terms of the Creative Commons Attribution Non-Commercial License (http://creativecommons. org/licenses/by-nc/3.0) which permits unrestricted non-commercial use, distribution, and reproduction in any medium, provided the original work is properly cited.

*Correspondence: MiyakoTakaki, PhD

Department of Molecular Pathology, Nara Medical University School of Medicine, 840 Shijo-cho, Kashihara, Nara 634-8521, Japan Tel: +81-744-23-9951, Fax: +81-744-25-7308, E-mail: mtakaki@naramed-u.ac.jp

Financial support: This work was supported by Grants-in-aid for Scientific Research (Grant No. 20659210, 23390330 and 24650325 for Miyako Takaki) from the Ministry of Education, Science, Sports and Culture of Japan. The funders had no role in study design, data collection and analysis, decision to publish, or preparation of the manuscript.

Conflicts of interest: None.

Author contributions: Miyako Takaki designed and supervised the present study and performed the data analysis and drafted manuscript. Kei Goto conducted experiments and obtained the data and partly analyzed the data. Isao Kawahara conducted experiments and obtained the data and partly analyzed the data. 


\section{Introduction}

We have reported a novel approach in vivo to reconstruct the enteric neural circuitry that mediates a fundamental distal gut reflex. ${ }^{1-4}$ The neural circuit insult was performed in guinea pigs by rectal transection and subsequent end-to-end one layer anastomosis. ${ }^{5,6}$ Brain-derived neurotrophic factor (BDNF) applied locally at the anastomosis promoted regeneration of the distal gut reflex pathways in the enteric nervous system (ENS) and repaired the anal dysfunction. ${ }^{6,7}$

BDNF, however, has serious detrimental actions such as pro-inflammatory action on the anastomosis and thus we explored a small molecule candidate promoting enteric neurogenesis. We found a brief report showing that some 5-hydroxytryptamine 4 receptor $\left(5-\mathrm{HT}_{4} \mathrm{R}\right)$ agonists increased neuronal numbers and length of neurites in enteric neurons in vitro from immunoselected neural crest (NC)-derived precursors in an abstract form. ${ }^{8}$

Therefore, we subsequently explored a novel approach in vivo to reconstruct the enteric neural circuitry in the distal gut of guinea pigs ${ }^{9}$ and rats ${ }^{10}$ by application of an $5-\mathrm{HT}_{4} \mathrm{R}$ agonist.

Jackie D Wood introduced our studies and Gershon's work as follows. ${ }^{11}$ Laboratories of Takaki at Nara Medical University, Japan and Gershon at Columbia University, New York have convincing evidence for enteric neurogenesis from indwelling stem cell populations. ${ }^{6,7,9,12}$ Takaki directed her attention to restoration of functional recto-anal inhibitory reflex connections and defecation following resection and anastomosis in a guinea pig model and published the first evidence that serotonergic action at the $5-\mathrm{HT}_{4} \mathrm{R}$ subtype might be a signal for differentiation of ENS stem cells into functional neurons that become "wired" into a reflex circuit that restored functional large intestinal motility. ${ }^{6,7,9}$

The idea that the gut contains serotonergic neurons has been controversial. Because enteric neurons take up 5-hydroxytryptamine (5-HT), ${ }^{13-17}$ 5-HT-containing neurons have been called "5-HT accumulating," to suggest that their 5-HT is derived from the enetrochromaffin (EC) cell. ${ }^{18}$ Mucosal 5-HT, however, does not normally reach myenteric ganglia. ${ }^{19}$ Nevertheless, stimulated enteric neurons release 5 -HT; ${ }^{19}$ moreover, 5-HT receptor blocking anti-idiotypic antibodies ${ }^{20}$ and acute 5-HT depletion $^{21}$ abolish putatively serotonergic slow excitatory post-synaptic potentials (EPSPs) mediated by $5-\mathrm{HT}_{1 \mathrm{p} .}{ }^{22,23}$ Criteria needed to establish 5-HT as an enteric neurotransmitter ${ }^{24}$ were finally completed by the discovery that enteric neurons express trypto- phan hydroxylase $2(\mathrm{TPH} 2){ }^{25}$

The gut contains a large 5-HT pool in EC cells and a smaller 5-HT pool in the ENS. During development, enteric neurons are generated asynchronously. Serotonergic neurons, which arise early, affect development/survival of later-born dopaminergic, gamma-aminobutyric acidergic, nitrergic, and calcitonin generelated peptide-expressing neurons and are essential for gastrointestinal motility. The 5-HT biosynthesis depends on tryptophan hydroxylase 1 (TPH1) in EC cells and on TPH2 in neurons; therefore, deletion of TPH2, but not TPH1, decreased myenteric neuronal density and proportions of dopaminergic and gamma-aminobutyric acidergic neurons. Addition of 5-HT to cultures of isolated enteric neural crest-derived cells (ENCDCs) promoted total and dopaminergic neuronal development. Moreover, serotonergic neurons promote development/survival of some classes of late-born enteric neurons, including dopaminergic neurons. ${ }^{26}$

Serotonin (5-HT) might be an enteric neuronal growth factor which was first suggested by observations that $5-\mathrm{HT}_{2 \mathrm{~B}}$ receptors are neuronal, developmentally regulated, and promote development of neurons from isolated ENCDCs. ${ }^{27}$ Subsequently, 5$\mathrm{HT}_{4} \mathrm{Rs}$ were demonstrated to be neuroprotective and to promote the development of new neurons from adult stem cells. ${ }^{12,28}$ Because enteric neurons are born asynchronously ${ }^{29}$ and serotonergic neurons are among the first to arise, ${ }^{29-31}$ it follows that serotonergic neurons coexist with dividing ENCDCs, some of which to receive synapses. ${ }^{32}$ It is thus plausible that serotonergic input influences the fate of ENCDCs.

We applied a $5-\mathrm{HT}_{4} \mathrm{R}$ agonist, mosapride citrate (MOS) locally at the anastomosis in guinea pigs ${ }^{9}$ or orally by the drinking water in rats ${ }^{10}$ for 2-4 weeks. Furthermore, we examined neurofilament (NF)-, 5- $\mathrm{HT}_{4} \mathrm{R}$ - and 5-bromo-2'-deoxyuridine (BrdU)-positive cells in the newly formed granulation tissue at the anastomotic site 2-4 weeks after enteric nerve circuit insult. Possible neural stem cell markers, anti-distal less homeobox 2 (DLX2)- and p75 neurotrophin receptor (NTR)-positive cells, and $\mathrm{NF}$-positive cells were also examined during the same time period.

We also developed a spontaneously contracting gut differentiated from mouse embryonic stem (ES) cells (ES gut) using an embryoid body $(\mathrm{EB})^{33}$ culture system. ${ }^{34}$ Although in these ES guts, enteric neural networks were not identified, we succeeded in forming dense enteric neural networks by MOS added only during EB formation. ${ }^{35}$

In the small intestine in H-line: Thy 1 promoter green fluo- 
rescent protein (GFP) mice, we obtained clear 3-dimensional in vivo imaging of enteric neurons that were newly generated through oral application of MOS after gut transection and anastomosis. ${ }^{36}$ BrdU- and NF-positive cells were identified as new enteric neurons.

All these results confirm that activation of enteric neural $5-\mathrm{HT}_{4} \mathrm{R}$ by MOS promotes in vivo and in vitro formation of new enteric neurons, indicating that treatment with $5-\mathrm{HT}_{4} \mathrm{R}$ agonists could be a novel therapy for generating new enteric neurons to rescue aganglionic gut disorders.

\section{Development of Enteric Neurons in the Gastrointestinal Tract}

The ENS provides the intrinsic innervation of the bowel, consisting of two layers of ganglia and fibers encircling the gastrointestinal tract. The ENS is vital for life and is capable of autonomous regulation of motility and secretion. The ENS originates from the NC, mostly from the vagal levels of the neuraxis, which invades, proliferates, and migrates within the intestinal wall until the entire bowel is colonized with ENCDCs. After initial migration, the ENS develops further by responding to guidance factors and morphogens that pattern the bowel concentrically, differentiating into glia and neuronal subtypes and wiring together to form a functional nervous system.

Molecules controlling this process, including glial cell-derived neurotrophic factor (GDNF) and its receptor RET, endothelin-3 (EDN3) and its receptor endothelin receptor type B (EDNRB), and transcription factors such as sex determining region Y-box 10 and paired-like homeobox $2 b$, are required for ENS development in humans. ${ }^{37-39}$

Understanding of ENS development is still a work in progress. Major morphological and electrophysiological changes in enteric neurons occur postnatally, which could underlie changes in gut motility during development. ${ }^{40}$

\section{Potential Therapy for Enteric Nervous System Deficient Diseases}

Developmental studies in model organisms and genetic studies of the most common congenital disease of the ENS, Hirschsprung disease, have provided a detailed understanding of ENS development. ${ }^{41}$ Rodents that are deficient for GDNF or RET (GDNF receptor), ${ }^{42-45}$ or EDN3 or EDNRB ${ }^{46-48}$ exhibit aganglionic megacolon, Hirschsprung disease.
Neural crest stem cells (NCSCs) never migrate into the aganglionic portion of the gut in animals affected by RET or EDNRB deficiency, despite the presence of NCSCs in region of the foregut and mid-gut that are colonized by NC. ${ }^{49,50}$ These observations raise the possibility of improving the treatment of Hirschsprung disease by transplanting NCSCs into the aganglionic portion of the gut to generate enteric ganglia by bypassing the migrating defects. ${ }^{49,51-53}$

Flow-cytometrically purified NCSCs from the ENS (gut $\mathrm{NCSC}$ ) migrated into the developing gut and formed enteric neurons. However, sciatic nerve NCSCs failed to migrate into the gut or to make enteric neurons, even when transplanted into the gut wall. Therefore, enteric potential is not a general property of NCSCs. ${ }^{54}$ It is critical to match the physiological properties of neural stem cells to the goals of proposed cell therapies. ${ }^{54}$

However, neuroepithelial stem cells (NESCs) harvested from the neural tube of embryonic rats can differentiate into NCSCs, which in turn generate peripheral nervous system derivatives. NESCs have a very broad developmental capacity and may generate a multiple of cell types and thus NESCs transplanted into the surviving denervated colon could differentiate into neurons and glial cells in vivo. ${ }^{55}$

$\mathrm{NC}$ cells are stem cells that are specified within the embryonic neuroectodermal epithelium and migrate to stereotyped peripheral sites for differentiation into many cell types. Several neurocristopathies involve a deficit of NC-derived cells, raising the possibility of stem cell therapy. In Hirschsprung's disease the distal bowel lacks an ENS caused by a failure of colonization by NC-derived cells. A robust method of producing migrating NC-like cells from human embryonic stem cells (hESCs)-derived neural progenitors using a coculture system of mouse embryonic fibroblasts has been developed. Subsequent exposure to Y27632, a smallmolecule inhibitor of the Rho effectors ROCKI/II, dramatically increased the efficiency of differentiation into NC-like cells, identified by marker expression in vitro. ${ }^{33}$

$\mathrm{NC}$-like cells derived by this method were able to migrate along NC pathways in avian embryos in ovo and within explants of murine bowel, and to differentiate into cells with neuronal and glial markers. This was the first report of the use of a small molecule to induce cells with NC characteristics from ES cells that can migrate and generate neurons and support cells in complex tissue. ${ }^{33}$ Furthermore, this study demonstrated that small-molecule regulators of ROCKI/II signaling might be valuable tools for stem cell research aimed at treatment of neurocristopathies.

Like central nervous system (CNS)-derived stem cells ${ }^{56}$ and 
NC-derived stem/progenitor cells derived from the gut, ${ }^{51,54,57}$ hESC-derived cells are a potential source of NC-like cells to generate enteric neurons or other $\mathrm{NC}$ derivatives in diseases such as Hirschsprung's disease. The data in this study provide a foundation for the production of an unlimited number of enteric neurons and other NC derivatives from patient-derived induced pluripotent stem (iPS) cells. ${ }^{33}$

Although there exist a great deal of therapeutic challenges for Hirschsprung disease, we explored a small molecule candidate promoting enteric neurogenesis following the neural circuit insult in the ENS. If such candidate is effective by oral application, taking such drug could easily repair any deficiency in the ENS.

\section{Differentiation of Enteric Neurons From Mouse Embryonic Stem Cells}

\section{Brain-derived Neurotrophic Factor}

Using an EB culture system, a functional organ-like cluster, ES gut was developed. Each ES gut exhibited spontaneous contractions but did not exhibit distinct peristalsis-like movements. In these spontaneously contracting ES guts, dense distributions of interstitial cells of Cajal (c-kit [a transmembrane receptor that has tyrosine kinase activity]-positive cells; gut pacemaker cells) and smooth muscle cells were discernibly identified; ${ }^{58}$ however, enteric neural ganglia were absent in the spontaneously differentiated ES gut. By adding BDNF only during EB formation, in vitro formation of enteric neural ganglia with connecting nerve fiber tracts (ENS) was firstly succeeded in the ES gut. ${ }^{34}$ The ES gut with ENS exhibited strong peristalsis-like movements, indicating this ENS was functioning physiologically. During EB culture in $\mathrm{BDNF}+$ medium, each immunoreactivity was associated with NC marker, proto-oncogene tyrosine-protein kinase receptor ret precursor (c-RET) or p75 NTR. These results indicated that the mouse ES gut ENS is differentiated from ENCDCs. ${ }^{34}$

Although EDNRB is briefly required to mediate migration of gut NCSCs, ${ }^{50}$ the EDNRB agonist IRL-1620 did not stimulate differentiation of enteric neural ganglia in this ES gut. ${ }^{34}$ This result is consistent with an earlier report that EDN3 acts via EDNRB to inhibit in vitro development of enteric neurons. ${ }^{59}$

\section{The 5-hydroxytryptamine 4 Receptor Agonist}

In spontaneously contracting ES guts as mentioned above, where enteric neural networks were not identified, a $5-\mathrm{HT}_{4} \mathrm{R}-\mathrm{ag}-$ onist, MOS added during EB formation succeeded in forming dense enteric neural networks. Addition of a $5-\mathrm{HT}_{4} \mathrm{R}$-antagonist, GR113808 (GR) abolished the 5- $\mathrm{HT}_{4} \mathrm{R}$-agonist-induced formation of enteric neural networks. The $5-\mathrm{HT}_{4} \mathrm{R}$-agonist up-regulated the expression of mRNA of $5-\mathrm{HT}_{4} \mathrm{R}$ and the $5-\mathrm{HT}_{4} \mathrm{R}$-antagonist abolished this upregulation. Though less potent, 5-HT per se exerted similar effects to those of 5- $\mathrm{HT}_{4} \mathrm{R}$ agonist, however the underlying mechanism for this difference remains unknown. The results suggest $5-\mathrm{HT}_{4} \mathrm{R}$-agonist differentiated enteric neural networks, mediated via activation of $5-\mathrm{HT}_{4} \mathrm{R}$ in the $\mathrm{ES}$ gut. ${ }^{35}$

It has also been shown that $5-\mathrm{HT}_{4} \mathrm{R}$ agonists play a role not only in the differentiation but also in neuroprotection and neurogenesis of enteric neurons during development. ${ }^{12,28}$ Therefore, it seems likely that application of $5-\mathrm{HT}_{4} \mathrm{R}$ agonists increases differentiation of enteric neurons from ES cells, possibly mediated via $\mathrm{NC}$-derived precursors, and the possibility of $5-\mathrm{HT}_{4} \mathrm{R}$-mediated neuroprotection cannot be excluded.

In addition, since the expression of $5-\mathrm{HT}_{2 \mathrm{~B}}$ receptors in the fetal ENS of fetal mice and the role of $5-\mathrm{HT}_{2 \mathrm{~B}}$ receptors in the promotion of neuronal precursor differentiation of ENS during development have been reported, ${ }^{27}$ the possibility that $5-\mathrm{HT}_{2 \mathrm{~B}}$ receptors play a role in the enteric neuronal differentiation in $\mathrm{ES}$ gut-like structure also cannot be excluded.

\section{The 5-hydroxytryptamine Receptors}

The 5-HT receptors are widely expressed within the gastrointestinal tract, and 5 of the 7 known families, $5-\mathrm{HT}_{1}, 5-\mathrm{HT}_{2}$, $5-\mathrm{HT}_{3}, 5-\mathrm{HT}_{4}$ and $5-\mathrm{HT}_{7}$ receptors, are expressed in the gut and can affect gut functions. ${ }^{60}$ The $5-\mathrm{HT}_{3}$ and $5-\mathrm{HT}_{4}$ receptor subtypes have been most extensively studied in the gut, and have been targeted for the treatment of diarrhea and constipation, respectively. ${ }^{61}$

\section{The 5-hydroxytryptamine 2B Receptor}

The 5 -HT is presumed to promote the differentiation of enteric neurons by stimulating a developmentally regulated receptor expressed by crest-derived neuronal progenitors. The 5-HT and 5- $\mathrm{HT}_{2}$ agonist ( \pm )-2,5-dimethoxy-4-iodoamphetamine $\mathrm{HCl}$ (DOI) enhanced in vitro differentiation of enteric neurons, both in dissociated cultures of mixed cells and in cultures of crest-derived cells isolated from the gut by immunoselection with antibodies to p75 NTR. The promotion of in vitro neuronal differentiation by $5-\mathrm{HT}$ and DOI was blocked by the $5-\mathrm{HT}_{1 / 2}$ antago- 
nist methysergide, the pan-5- $\mathrm{HT}_{2}$ antagonist ritanserin, and the

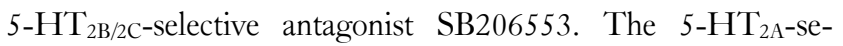
lective antagonist ketanserin did not completely block the developmental effects of 5-HT. The 5-HT induced the nuclear translocation of mitogen-activated protein kinase. This effect was blocked by ritanserin. Messenger RNA encoding 5- $\mathrm{HT}_{2 \mathrm{~A}}$ and $5-\mathrm{HT}_{2 \mathrm{~B}}$ receptors was detected in the fetal bowel (stomach and small and large intestine), but that encoding the $5-\mathrm{HT}_{2 \mathrm{C}}$ receptor was not. Messenger RNA encoding the $5-\mathrm{HT}_{2 \mathrm{~B}}$ receptor and $5-\mathrm{HT}_{2 \mathrm{~B}}$ immunoreactivity were found to be abundant in primordial but not in mature myenteric ganglia. The $5-\mathrm{HT}_{2 \mathrm{~B}}-\mathrm{im}-$ munoreactive cells were found to be a subset of cells that expressed the neuronal marker PGP 9.5. These data demonstrate that $5-\mathrm{HT}_{2 \mathrm{~B}}$ receptors are expressed by enteric neurons. It is possible that by stimulating $5-\mathrm{HT}_{2 \mathrm{~B}}$ receptors, $5-\mathrm{HT}$ affects the fate of the large subset of enteric neurons that arises after the development of endogenous sources of 5-HT. ${ }^{27}$

\section{The 5-hydroxytryptamine 3 Receptor}

The $5-\mathrm{HT}_{3}$ receptors are both of intrinsic and extrinsic origins in rat colon and guinea pig ileum. ${ }^{62,63}$ Application of 5-HT to the mucosa activates $5-\mathrm{HT}_{3}$ receptor that triggers action potential generation in mucosal nerve terminal of myenteric $\mathrm{AH}$ neurons. ${ }^{63}$ Therefore, $5-\mathrm{HT}_{3}$ receptor antagonists have been used to treat functional disorders with diarrhea. ${ }^{61} 5-\mathrm{HT}_{3}$ antagonists have been shown to be effective in treating both the diarrhea and abdominal discomfort symptoms of irritable bowel syndrome-diarrhea type (IBS-D). ${ }^{64,65}$ Although the precise mechanisms of action of $5-\mathrm{HT}_{3}$ antagonists have not been definitively determined, it is possible that they inhibit $5-\mathrm{HT}_{3}$ receptors located on intrinsic and extrinsic afferent nerve fibers in the mucosa that are activated by 5-HT released from enterochromaffin cells. They also inhibit the stimulation of $5-\mathrm{HT}_{3}$ receptors on interneurons and motor neurons that contribute to fast EPSPs. ${ }^{66}$ Collectively, these actions would decrease propulsive motility and secretion locally within the gut, thus alleviating diarrhea, as well as decreased signalling from spinal afferent nerves that deliver signals of pain and discomfort to the CNS. Moreover, upregulation of $5-\mathrm{HT}_{3}$ receptors in the mucosa/submucosal layer is involved to restore the delayed transit after the parasympathetic denervation in rats. ${ }^{67}$

Specific roles of enteric $5-\mathrm{HT}_{3 \mathrm{~B}}$ receptors have been reported in serotonin transporter (SERT) ${ }^{-/-}$mice. ${ }^{68}$ Adaptive changes in enteric $5-\mathrm{HT}_{3}$ receptors may help $\mathrm{SERT}^{-1-}$ mice survive despite inefficient 5-HT inactivation. Expression of mRNA en- coding enteric 5- $\mathrm{HT}_{3 \mathrm{~A}}$ subunits was similar in $\mathrm{SERT}^{+/+}$and $\mathrm{SERT}^{-1-}$ mice, but that encoding enteric $5-\mathrm{HT}_{3 \mathrm{~B}}$ subunits found in epithelial cells and enteric neurons was markedly decreased in $\mathrm{SERT}^{-/-}$mice. The EC50 of the 5-HT response was lower in $\mathrm{SERT}^{+/+}$than in $\mathrm{SERT}^{-/-}$mice and the 5-HT response was desensitized rapidly in many $\mathrm{SERT}^{-/-}$neurons. Adaptive changes thus occur in the subunit composition of enteric $5-\mathrm{HT}_{3}$ receptors of $\mathrm{SERT}^{-/-}$mice that are reflected in $5-\mathrm{HT}_{3}$ receptor affinity and desensitization. ${ }^{68}$

\section{The 5-hydroxytryptamine 4 Receptor Splice Variant}

Alternative splicing produced several variants of the 5$\mathrm{HT}_{4} \mathrm{R}^{69,70}$ No significant differences were detected in competition binding experiments using reference $5-\mathrm{HT}_{4} \mathrm{R}$ ligands. However, the broadly used $5-\mathrm{HT}_{4} \mathrm{R}$ antagonist GR discriminated functionally among the receptor variants investigated. The importance of variations introduced by splicing for receptor pharmacology may help in the understanding of conflicting results seen with $5-\mathrm{HT}_{4} \mathrm{R}$ ligands in different model systems. ${ }^{70}$

\section{Acute Actions of 5-hydroxytryptamine 4 Receptor Agonists in the Gut}

\section{Defecation}

Agonists of the $5-\mathrm{HT}_{4} \mathrm{R}$ alleviate constipation in irritable bowel syndrome-constipation type (IBS-C) and in chronic constipation, provide pain relief in IBS-C, and accelerate the rate of gastric emptying. ${ }^{60,61,71-73}$ In parkinsonian patients, MOS actually augmented lower gastrointestinal tract motility and thereby ameliorated constipation probably via a neural mechanism. ${ }^{74}$ Moreover, upregulation of $5-\mathrm{HT}_{4} \mathrm{R}$ in the mucosa/submucosal layer is involved in restoring the delayed transit after the parasympathetic denervation in rats. ${ }^{67}$

As for the moderate defecation model, we developed the rectal gradual and sustained distension-evoked reflex rectal (R-R) contractions and simultaneous internal anal sphincter (R-IAS) relaxations through the extrinsic and intrinsic cholinergic excitatory and nitrergic inhibitory nerve pathways in guinea pigs. ${ }^{2}$ Using this model, whether a prokinetic benzamide MOS enhances the R-R and R-IAS reflexes mediated via $5-\mathrm{HT}_{4} \mathrm{R}$ was examined. Intravenous administration of MOS dose-dependently enhanced both R-R and R-IAS reflex responses maximally increased up to approximately $200 \%$. A specific $5-\mathrm{HT}_{4} \mathrm{R}$ antagonist, GR, antagonized the enhancement of the R-R and R-IAS 
reflexes induced by MOS. The results indicate that MOS enhanced the R-R and R-IAS reflexes mediated through 5- $\mathrm{HT}_{4} \mathrm{R}^{3}{ }^{3}$

In order to reveal the site of action of MOS inducing enhancement of the R-R and R-IAS reflexes mediated through 5- $\mathrm{HT}_{4} \mathrm{R}$, the intrinsic R-R and R-IAS reflex model was created by pithing (destruction of the lumbar and sacral cords; PITH). The reflexes were unchanged between days 4-9 after PITH. MOS dose-dependently increased both intrinsic R-R (maximum: 182\%) and R-IAS reflex responses up to approximately 200-300\% 6-9 days after PITH. The 5- $\mathrm{HT}_{4} \mathrm{R}$ antagonist, GR decreased the R-R and R-IAS reflex by approximately $50 \%$ and antagonized the effect of MOS. The results indicate that MOS moderately enhanced intrinsic R-R and R-IAS reflexes which were functionally compensated after deprivation of extrinsic nerves, mediated through endogenously active intrinsic $5-\mathrm{HT}_{4} \mathrm{R}^{4}$

\section{Inflammation}

It has been reported that 5-HT plays a role in regulating intestinal inflammation and that the potentiation of serotonergic signaling that results from SERT deletion is proinflammatory. ${ }^{75}$ However, it is recently shown that $5-\mathrm{HT}_{4} \mathrm{R}$ agonists have the antiulcerogenic action against gastric mucosal ulcers induced by NSAIDs $^{76}$ and anti-inflammatory potency. ${ }^{77}$

After intestinal manipulation (IM), ileal circular muscle contractility in vitro and gastrointestinal transit in vivo were reduced and the number of macrophages and neutrophils increased in the inflamed muscle layer, resulting in the induction of inflammatory mediators such as IL- $1 \alpha$, IL-6, TNF- $\alpha$, monocyte chemo-attractant protein 1 and inducible nitric oxide synthase. Both MOS and a potent and selective $5-\mathrm{HT}_{4} \mathrm{R}$ partial agonist CJ-033466 significantly attenuated not only the intestinal motility dysfunction but also the leucocyte infiltration and inflammatory mediator expression after IM.

The autonomic ganglionic blocker hexamethonium and the $\alpha 7$-nicotinic acetylcholine receptor $(\alpha 7 \mathrm{nAChR})$ antagonist methyllycaconitine citrate blocked MOS-mediated ameliorative actions. Immunohistochemically, $\alpha 7 \mathrm{nAChR}$ is expressed by monocytes/macrophages but not by neutrophils in the inflamed intestine. Stimulating the $5-\mathrm{HT}_{4} \mathrm{R}$ accelerates acetylcholine $(\mathrm{ACh})$ release from cholinergic myenteric neurons, which subsequently activates $\alpha 7 \mathrm{nAChR}$ on activated monocytes/macrophages to inhibit their inflammatory reactions in the muscle layer. $5-\mathrm{HT}_{4} \mathrm{R}$ agonists might serve as novel therapeutic agents for postoperative ileus characterized by anti-inflammatory potency. ${ }^{77}$

\section{In Vivo Enteric Neurogenic Actions of Brain-derived Neurotrophic Factor in the Distal Gut}

After ablation of the myenteric plexus of the mouse colon with the detergent benzalkonium chloride (BAC), new neurons were present in the myenteric region, along with regenerating nerve fibers by day 30 ( 4 weeks). The results provide evidence for the presence of stem cells and for an adult neurogenesis in this plexus. $^{78}$

We explored a novel approach to repairing the defecation reflex dysfunction by using the plasticity of enteric nervous pathways after impairment of the defecation reflex by rectal transection (RT) + rectal anastomosis (RA). Eight weeks after sectioning of intrinsic reflex nerve pathways in the rectum, the R-IAS reflex relaxations recovered to the control level, accompanied with regeneration of reflex pathways. Two weeks after local treatment with BDNF at the rectal anastomotic site, the R-IAS reflex relaxation responses were recovered and some bundles of fine nerve fibers were shown to interconnect the oral and anal ends of the myenteric plexus. ${ }^{6}$ These results suggest a possibility for repairing the anal dysfunction by promoting regeneration of the reflex pathways in the ENS with local application of BDNF.

Simultaneously, we found new neurons in the granulation tissue at the anastomotic site treated with BDNF. These neurons expressed neural stem cell markers such as p75 NTR in the ENS and DLX2 originally identified in the CNS. ${ }^{79}$ These neurons also expressed the cell proliferating marker, proliferation cell nuclear antigen (PCNA). BrdU/NF concurrent labeling cells were found in the granulation tissue at the anastomotic site treated with BDNF. Taken together, BDNF might have formed new neurons from neural stem cells in the newly formed granulation tissue at the anastomotic site and/or promoted migration of neurons into the site from neural stem cells. ${ }^{6}$

On the other hand, the role of interstitial cells of Cajal (ICCs) in the defecation reflex is still controversial. ${ }^{80,81}$ Correlations between the number of ICCs and defecation disturbance were assessed for the neorectum after anterior resection of the rectum. Expression of ICCs in the neorectum did not recover to preoperative levels over time. There was no correlation between the number of ICCs and the time interval from the initial anterior resection of the neorectum, nor was there any relationship between the number of ICCs and defecation disturbance. ${ }^{80}$ However, 
there is a report showing that, in ICC-deficient mutant mice, the rectoanal relaxation reflex was largely attenuated. This result indicates that ICC has a distinct role in the rectoanal relaxation reflex. ${ }^{81}$ In the above RT + RA model, the distribution of intramuscular ICC and myenteric plexus ICC had already recovered 2 weeks after RT + RA, but nerve components of the R-IAS reflex pathway had not, suggesting that regeneration of ICC networks preceded that of myenteric neurons, although whether ICCs have a distinct role on the rectoanal relaxation reflex or not was not determined. ${ }^{6}$

In the mouse ileum, twenty-four hours after resection and anastomosis, electrical rhythmicity largely recovered and ICC networks appeared normal at all regions examined, although the recovery of myenteric neurons was not analyzed (remained unknown). ${ }^{82}$ On the other hand, in the small intestine of adult guinea pigs, ICCs regenerated and restored the normal distribution five months (long period) after semitransection and anastomosis. ${ }^{83}$ However, 10 weeks after the ablation of myenteric plexus and myenteric plexus ICC with the detergent BAC in the mouse colon, no ICCs were present in the BAC-treated area, despite nerve fibers had started to grow back into the treated area. ${ }^{84}$ The difference in recovery time among these studies may be partly related to the different ablation process of myenteric plexus and ICCs.

In most patients, the rectoanal inhibitory reflex recovers 1-2 years after the lower anterior resection of the rectum for carcinoma. ${ }^{85,86}$ The recovery of the reflex is based on the regeneration of the enteric nerves crossing the anastomotic site. ${ }^{86}$ The possibility that an intrinsic defecation reflex mediated via ENS recovers earlier than 1-2 years after the lower anterior resection of the rectum is presented by the result of animal experiments. ${ }^{6}$ The local treatment with $\mathrm{BDNF}$ at the anastomotic site shortens the regeneration period of the enteric nerve pathway. $^{6}$

\section{Enteric Neurogenic Actions of the 5-hydroxytryptamine 4 Receptor Agonist in the Distal Gut}

A similar approach in vivo to reconstruct the enteric neural circuitry that mediates a fundamental distal gut reflex after the neural circuit insult by RT + RA was performed in guinea pigs and rats. The $5-\mathrm{HT}_{4} \mathrm{R}$ agonist, MOS was applied locally using gelatin sponge (GS) at the anastomotic site and orally by the drinking water. MOS promoted the regeneration of the neural circuit in the impaired myenteric plexus and the recovery of the defecation reflex in the distal gut. Furthermore, MOS generated $\mathrm{NF}$-, 5- $\mathrm{HT}_{4} \mathrm{R}$ - and BrdU-positive cells and surprisingly formed neural network in the newly formed granulation tissue at the anastomotic site 2 weeks after enteric nerve circuit insult. Possible neural stem cell markers, DLX2- and p75 NTR-positive, and NF-positive cells increased during the same time period. The specific $5-\mathrm{HT}_{4} \mathrm{R}$ antagonist, GR inhibited all actions by MOS. ${ }^{9,10}$

Additional experiments involved subcutaneous implantation of GS at the neck for 3 days were performed. ${ }^{10} \mathrm{GS}$ was treated with DMSO, MOS, or GR+MOS. GS was removed for immunohistochemistry and quantitative reverse transcription- polymerase chain reaction (qRT-PCR). Effects of MOS on mobilization of PCNA-, DLX2-, 5 $\mathrm{HT}_{4} \mathrm{R}$-, and c-RET-positive cells into subcutaneously implanted GS at the neck were evaluated. MOS significantly increased the number of DLX2-, $5 \mathrm{HT}_{4} \mathrm{R}-$, and c-RET-positive cells in the implanted GS. No NF-positive cells were observed. ${ }^{10}$ DLX2- and $5 \mathrm{HT}_{4} \mathrm{R}$-positive cells are neural stem cells, and c-RET-positive cells are NC-derived stem cells. ${ }^{34}$ Therefore, it seems likely that MOS differentiates NC-derived stem cells into neural stem cells. ${ }^{87}$ These results were confirmed by similar results by qRT-PCR. In addition, GR antagonized MOS-induced increases of mRNA of DLX2, $5 \mathrm{HT}_{4} \mathrm{R}$, and c-RET to control level, respectively. These results indicate that activation of enteric neural $5-\mathrm{HT}_{4} \mathrm{R}$ promotes reconstruction of an enteric neural circuit leading to the recovery of the defecation reflex in the distal gut, and that this reconstruction involves neural stem cells. These findings indicate that treatment with $5-\mathrm{HT}_{4} \mathrm{R}$ could be a novel therapy for generating new enteric neurons to rescue aganglionic gut disorders.

$\mathrm{BDNF}$ and 5-HT are known to regulate synaptic plasticity, neurogenesis and neuronal survival in the adult brain. These two signals co-regulate one another such that 5-HT stimulates the expression of BDNF, and BDNF enhances the growth and survival of 5-HT neurons. ${ }^{88} \mathrm{BDNF}$ and its receptor tropomyosin-related kinase B proto-oncogenes (TrkB) have emerged as key mediators in the pathophysiology of several mood disorders, including anxiety and depression. Recently a low-molecular weight TrkB ligand (ANA-12; N2-(2-\{[(2-oxoazepan-3-yl) amino $]$ carbonyl $\}$ phenyl) benzo $[\beta]$ thiophene-2-carboxamine) that prevented activation of the receptor by BDNF with a high potency was identified. ${ }^{89}$ ANA-12 showed direct and selective binding to TrkB and inhibited processes downstream of TrkB without altering TrkA and TrkC functions. ANA-12 may be a valuable tool for studying BDNF/TrkB signaling and may constitute a lead 
compound for developing the next generation of therapeutic agents for the treatment of mood disorders. ${ }^{89}$

Therefore, we examined whether the enteric neurogenesis induced by MOS was blocked by ANA-12 using ES gut culture system. ${ }^{34,90}$ ANA-12 and MOS were added during EB culture period, but MOS-induced neural network-forming capacity was not affected by ANA-12. Although this is only small number of experiments, enteric neurogenesis induced by MOS seems not to mediate BDNF release from enteric neurons (our unpublished data).

\section{Enteric Neurogenic Actions of the 5-hydroxytryptamine 4 Receptor Agonist in the Mouse Proximal Gut}

Two-photon microscopy (2PM) allows cellular imaging several hundred microns deep in various organs of living animals and ex vivo specimens. This approach was used to achieve the first in vivo imaging of enteric neurons and nerve fibers in the mucosa, submucosa, submucosal and myenteric plexuses, and circular and longitudinal muscles of the proximal gut, ileum in GFP mice. ${ }^{36}$ Moreover, we obtained clear three-dimensional imaging of newly generated enteric neurons one week after gut transection and anastomosis. Oral application of MOS by drinking water facilitated formation of newly generated enteric neurons in the granulation tissue at the anastomosis. However, even 4 weeks after surgery, only a small number of newborn neurons were identified in the granulation tissue of vehicle-treated control animals. Most neurons were located within $100 \mu \mathrm{m}$ of the surface, close to the edge of the granulation tissue (Fig. 1, right). In the rat rectum, neural stem cells were distributed in the subserosal and longitudinal muscle layers (Fig. 1, left). ${ }^{36}$ These results suggested the possibility that neural stem cells were migrated from the outside of granulation tissue.

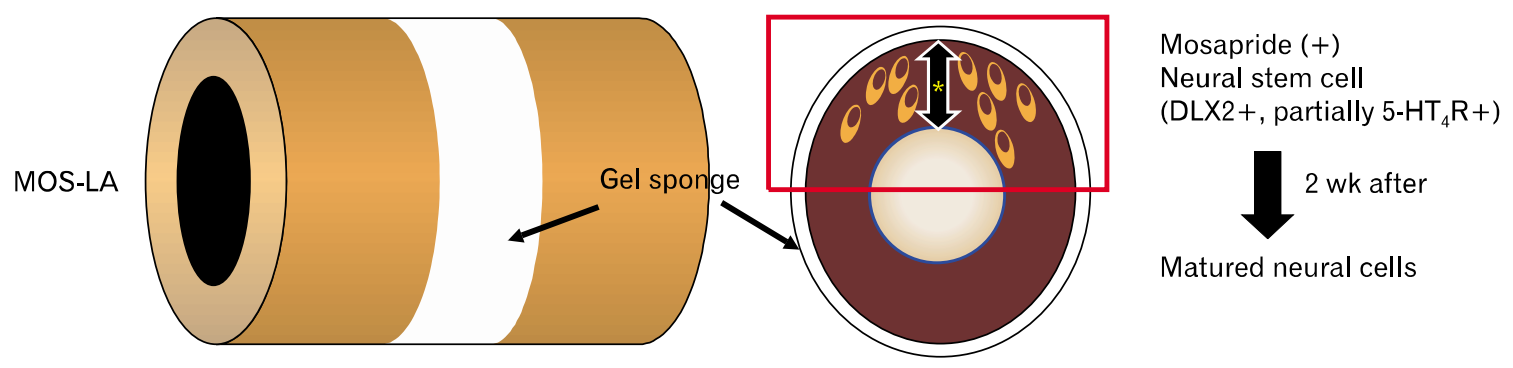

Layer

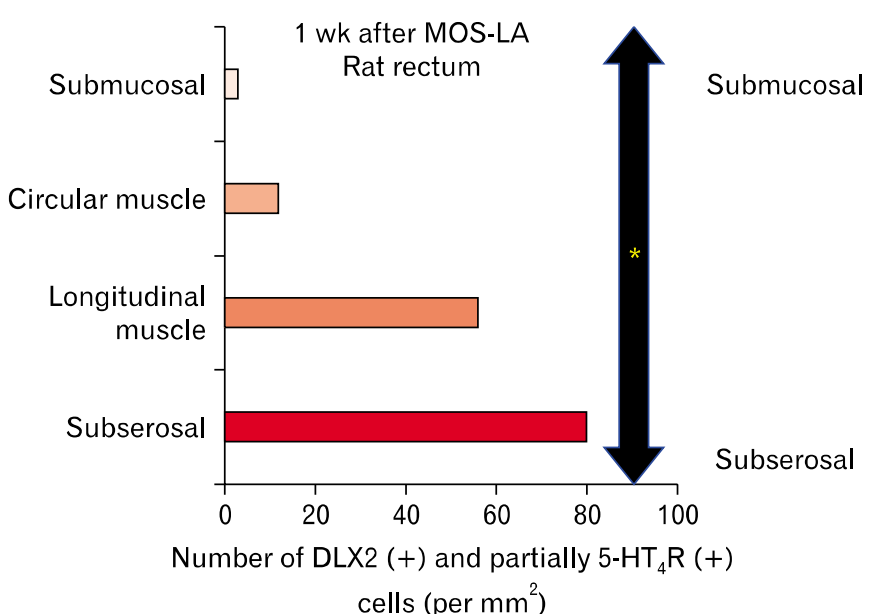

Depth $(\mu \mathrm{m})$ from serosa

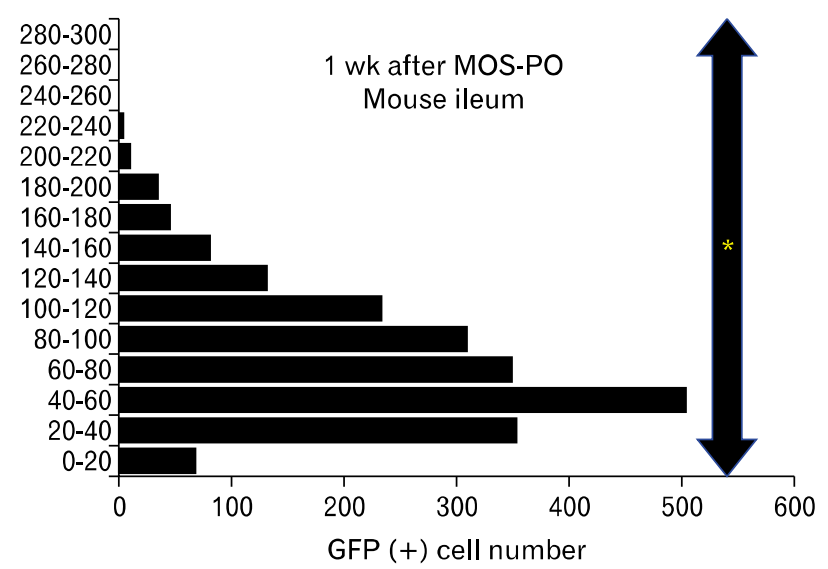

Figure 1. Distribution of migrated neural stem cells enhanced by a 5-hydroxytryptamine 4 receptor $\left(5-\mathrm{HT}_{4} \mathrm{R}\right)$ agonist mosapride citrate (MOS). Left: 1 week after transection and anastomosis in the rat rectum. Right: 1 week after transection and anastomosis in the H-line Thy 1 promoter green fluorescent protein (GFP) mouse ileum. DLX2-positive and partially 5- $\mathrm{HT}_{4} \mathrm{R}$-positive cells (left) and GFP-positive cells (right) corresponding to neural stem cells. MOS-LA, local application by gel sponge soaked with MOS; MOS-PO, oral application by drinking water containing MOS. Asterisk mark (*) indicates depth. 
Correctly identified fluorescent neurons by $2 \mathrm{PM}$ are proved to be neurons with an independent technique at the anastomotic site. NF-positive, DLX2-negative, BrdU-positive and GFPpositive cells are identified as a new neuron. NF-negative, DLX2positive, BrdU-positive and GFP-positive cells seem to be neural progenitors. ${ }^{36}$ At this anastomotic site, glia fibrillary acidic protein (GFAP)-positive enteric glial cells are not found. Taken together, it is evident that activation of enteric neural $5-\mathrm{HT}_{4} \mathrm{R}$ by MOS promotes formation of new enteric neurons also in mouse proximal gut, ileum.

\section{Effects of Selective Serotonin Reuptake Inhibitors on Neurogenesis}

The effects of an selective serotonin reuptake inhibitor (SSRI) fluoxetine were investigated on the process of differentiation from ES cells into neural cells using the stromal cell-derived inducing activity method. ${ }^{91}$ Fluoxetine treatment was found to enhance the expression of glial marker genes, as observed by immunocytochemical analysis or qRT-PCR. The promoter activity of glial marker genes was also significantly enhanced when cells were treated with fluoxetine. On the other hand, the expression of neuronal markers during ES cell differentiation into neural cells was inhibited by fluoxetine treatment. In addition, fluorescence activated cell sorting analysis revealed an increased population of glial cells in the differentiating ES cells treated with fluoxetine. These results suggest that fluoxetine could facilitate the differentiation of mouse ES cells into glial cell lineage, which may affect fetal neural development. ${ }^{91}$

The effect of fluoxetine on hippocampal neurogenesis in the adult rat was investigated using $\mathrm{BrdU}$ as a marker for dividing cells. ${ }^{92}$ Chronic fluoxetine treatment significantly increases the number of BrdU-labeled cells in the dentate gyrus and hilus of the hippocampus. Administration of several different classes of antidepressant, but not non-antidepressant, was associated with increase in the BrdU-labeled cell number, indicating that this is a common and selective action of antidepressants. Additional studies demonstrated that antidepressant treatment increases the proliferation of hippocampal cells and that these new cells mature and become neurons, as determined by triple labeling for $\mathrm{BrdU}$ and neuronal- or glial-specific markers. ${ }^{92}$

On the other hand, fluoxetine can reverse the established state of neuronal maturation in the adult mouse hippocampus, and up-regulation of $5-\mathrm{HT}_{4} \mathrm{R}$-mediated signaling may play a critical role in this distinct action of antidepressants. ${ }^{93}$ It was also shown that the $5-\mathrm{HT}_{4} \mathrm{R}$ is coupled to $\mathrm{G}$ protein Gs-cAMP cascades, and 5-HT-induced potentiation at the mossy fiber synapse is mediated by activation of $5-\mathrm{HT}_{4} \mathrm{R}$ and intracellular cAMP elevation. $^{94}$

An SSRI fluvoxamine maleate, which increases endogenous $5-\mathrm{HT}$, is presumed to repair enteric nerve fiber injury in the rat distal gut. Enteric nerve fiber injury was performed by RT + RA. Fluvoxamine was applied locally at the anastomotic site in comparison with the $5-\mathrm{HT}_{4} \mathrm{R}$ agonist MOS applied locally and orally. Unlike MOS, fluvoxamine failed to promote the regeneration of the nerve fiber tract across the anastomosis. ${ }^{10}$ Furthermore, fluvoxamine did not generate DLX2- and 5$\mathrm{HT}_{4} \mathrm{R}$-positive cells (neural stem cells) and/or NF-positive cells (neural cells) in newly formed granulation tissue at the anastomosis, whereas these cell types were observed in MOS-treated preparations. ${ }^{10}$ Anti-SERT immunoreactivity was observed in the intact myenteric plexus, but at the anastomotic site neither anti-SERT-immunoreactivity nor anti-NF-immunoreactivity was observed (our unpublished observation). From these results, at least endogenous 5-HT possibly accumulated in myenteric plexus around the anastomosis (not at the anastomosis) was not able to generate new enteric neurons, although the mechanisms for this failure of enteric neurogenesis remain unknown. In addition, considering from literatures reporting the effect of SSRIs in the hippocampus, ${ }^{91-93}$ it is plausible that SSRIs per se may promote or inhibit neural regeneration in the ENS.

\section{Possible Mechanisms for Mosapride Citrate-induced Enteric Neurogenesis}

Genes and/or other markers enable many of the putative progenitor stages of enteric neuronal development expression to be recognized. Ret encodes a transmembrane receptor kinase, RET, that dimerizes when activated by a complex that includes a member of the GDNF family of ligands and a preferred glycosylphosphatidyl-inositol-anchored co-receptor, GDNF family receptor $(\mathrm{GFR} \alpha 1){ }^{95}$ A common RET/GDNF/GFR $\alpha 1$-dependent progenitor gives rise to committed lineages both of enteric neurons ${ }^{96,97}$ and glia, which can be distinguished from ENCDC. ${ }^{37}$

The $5-\mathrm{HT}_{4} \mathrm{R}$ is coupled to $\mathrm{G}$ protein $\mathrm{G}_{\mathrm{s}}$-cAMP cascades, ${ }^{94}$ i.e., $\mathrm{G}$ protein coupled receptor (GPCR). MOS increased number of c-RET-positive cells and mRNA of c-RET in the implanted GS in rats mentioned above. ${ }^{10} \mathrm{C}$-RET is a GDNF receptor tyrosine kinase (RTK). GPCR-mediated signaling path- 
ways have been reported to include transactivation of RTKs; the differential involvement of RTKs and downstream signaling pathways activated in response to GPCR-mediated stimulation elicits a variety of cellular effects during development, proliferation, differentiation, survival, repair and synaptic transmission in the CNS. ${ }^{98}$ Therefore, it would be expected that 5- $\mathrm{HT}_{4} \mathrm{R}$ as GPCRs cross-communicates with c-RET as RTKs in the ENS (Fig. 2).

RET activation results in phosphorylation of several residues, including Y1015 and Y1062. Growth factor receptor-bound protein 2 and phospholipase $\mathrm{C} \gamma$ are required for proliferation and/or differentiation of ENS precursors. RAC, RHO and CDC42 regulate ENCDC migration and proliferation. Kinesin-like protein
KIF26A, Sprouty2 (SPRY2) and phosphatase and tensin homolog deleted from chromosome 10 (PTEN) are negative regulators of RET signalling: KIF26A binds to growth factor receptor-bound protein 2 and prevents RAS-ERK and PI3K signalling, whereas SPRY2 binds to RAS and RAF and blocks activation of the RAS-ERK pathway. PTEN regulates proliferation via PI3K and Akt (Fig. 2). ${ }^{38,39}$

Since protein kinase A is thought to integrate RET and EDNRB signalling pathways by RET phosphorylation at S696 and RAC activation, ${ }^{39}$ the possibility for protein kinase A activation by cAMP elevation induced by $5-\mathrm{HT}_{4} \mathrm{R}$ activation could not be excluded.

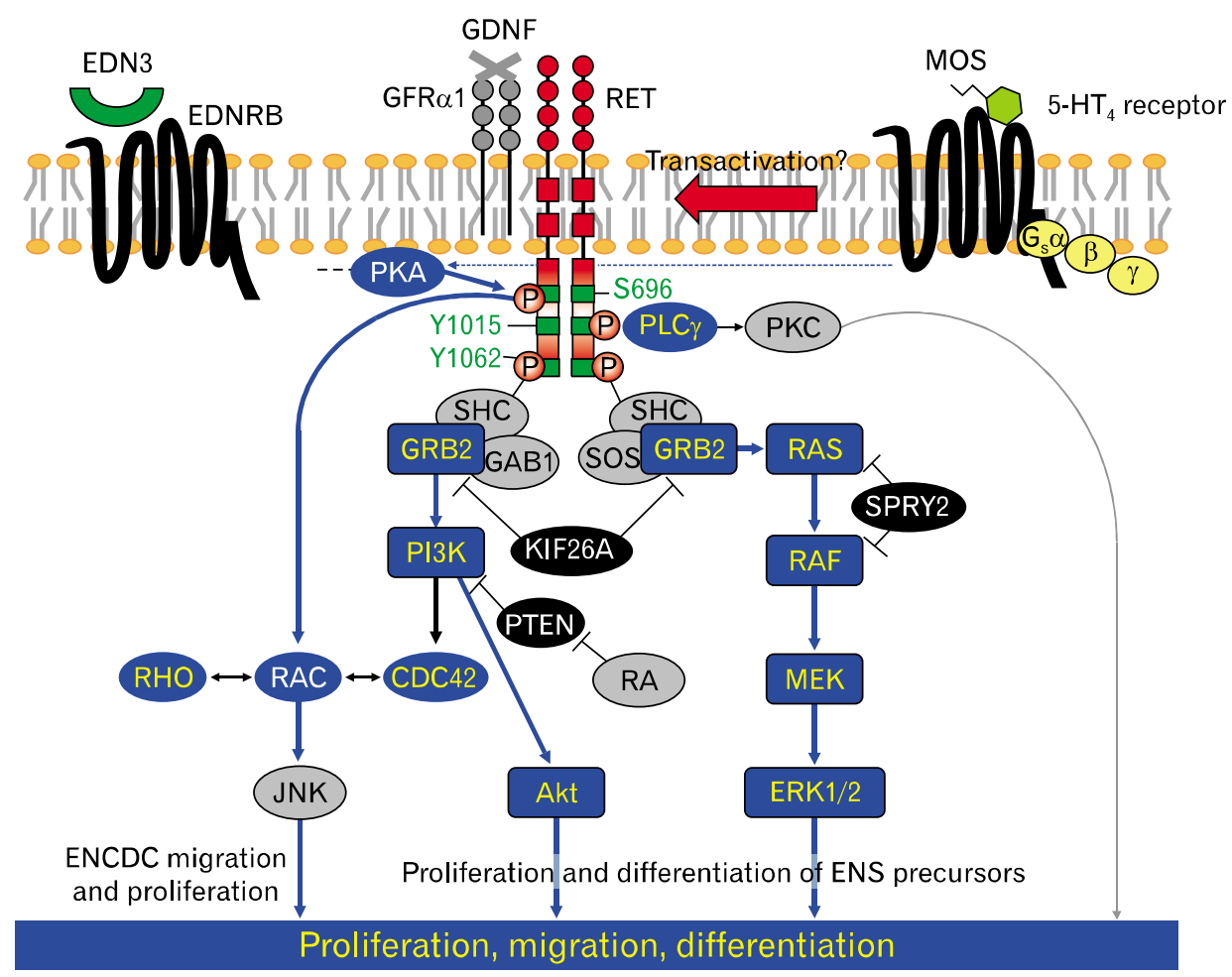

Figure 2. Possible signalling pathways involved in enteric neurogenesis by a 5-hydroxytryptamine 4 receptor $\left(5-\mathrm{HT}_{4} \mathrm{R}\right)$ agonist mosapride citrate (MOS). Main intracellular pathways activated by proto-oncogene tyrosine-protein kinase receptor Ret (RET) are shown. MOS activates a 5-HT $\mathrm{R}_{4}$, G protein coupled receptor (GPCR). This GPCR possibly does transactivation of RET. RET activation results in phosphorylation of several residues, including Y1015 and Y1062. Growth factor receptor-bound protein 2 (GRB2) and phospholipase C gamma (PLC $\gamma$ ) are required for proliferation and/or differentiation of enteric nervous system (ENS) precursors. RAC, RHO and CDC42 regulate enteric neural crest-derived cells (ENCDCs) migration and proliferation. Kinesin-like protein KIF26A (KIF26A), Sprouty2 (SPRY2) and phosphatase and tensin homolog (PTEN) are negative regulators of RET signalling: KIF26A binds to GRB2 and prevents RAS-ERK and phosphoinositide 3-kinase (PI3K) signalling, whereas SPRY2 binds to RAS and RAF and blocks activation of the RAS-ERK pathway. PTEN regulates proliferation via PI3K and Akt. Retinoic acid reduces PTEN levels in migrating ENCDCs and hence blocks the inhibitory effect of PTEN on RET signalling. Protein kinase A is thought to integrate RET and endothelin B receptor (EDNRB) and possibly 5- $\mathrm{HT}_{4} \mathrm{R}$ signalling pathways by RET phosphorylation at S696 and RAC activation. Modified from Obermayr et al. ${ }^{39} \mathrm{EDN} 3$, endothelin 3; GAB1, GRB2-associated binding protein 1; GDNF, glial cell line-derived neurotrophic factor; GRB2, growth factor receptor-bound protein 2; JNK, c-Jun- $\mathrm{NH}_{2}$-terminal kinase; $\mathrm{PKC}$, protein kinase $\mathrm{C}$; $\mathrm{S}$, serine; $\mathrm{Y}$, tyrosine. 


\section{Clinical Implication}

(1) Although we obtained the first ever clear 3-dimensional imaging of newly generated enteric neurons within the thick granulation tissue at the anastomosis in the gut of the living mouse using 2PM, it is difficult to use this technology for clinical application. However, in vivo imaging of the muscularis propria and myenteric neurons with probe-based confocal laser endomicroscopy in porcine models has been recently reported. ${ }^{99}$ To diagnose the MOS-induced enteric neurogenesis non-invasively, this technology would be promising.

(2) For the purpose of therapies, the advantage of using tissue-derived NC cells is that they can be generated autologously and thus not be immunorejected once transplanted back into the patient. ${ }^{33}$ Some studies state that NC-like cells isolated from adult non-neural tissues may be restricted in their differentiation potential and therefore be incapable of some lines of differentiation. ${ }^{100}$ However, other reports have suggested differently. ${ }^{101}$ Conversely, NC-like cells isolated from ES cells are not patient-specific and hence are subject to rejection, but are more likely to retain their full differentiation and functional potential. This caveat of patient specificity may now be addressed with the recent advancements of iPS cell technology. ${ }^{102,103}$ It is becoming more feasible that patient-specific iPS cell lines may be generated and perhaps therapeutically used. It is also very likely that the technologies and methods developed with human ES cells may be transferred to iPS cells and their neural derivatives.

(3) As more practical therapy for the present, taking the small molecule chemical compound $5-\mathrm{HT}_{4} \mathrm{R}$ agonist MOS will be an ideal therapy for the ENS deficient diseases without detrimental side effects, because MOS has been already and widely applied for functional dyspepsia, IBS-C and IBS-D patients.

\section{References}

1. Takaki M, Neya T, Nakayama S. Sympathetic activity in the recto-rectal reflex of the guinea pig. Pflugers Arch 1980;388:45-52.

2. Yamanouchi M, Shimatani H, Kadowaki M, et al. Integrative control of rectoanal reflex in guinea pigs through lumbar colonic nerves. Am J Physiol Gastrointest Liver Physiol 2002;283:G148-G156.

3. Shimatani H, Kojima Y, Kadowaki M, et al. A 5- $\mathrm{HT}_{4}$ agonist mosapride enhances rectorectal and rectoanal reflexes in guinea pigs. Am J Physiol Gastrointest Liver Physiol 2003;285:G389-G395.

4. Kojima Y, Nakagawa T, Katsui R, Fujii H, Nakajima Y, Takaki M. A 5- $\mathrm{HT}_{4}$ agonist, mosapride, enhances intrinsic rectorectal and rectoanalreflexes after removal of extrinsic nerves in guinea pigs. Am J Physiol Gastrointest Liver Physiol 2005;289:G351-G360.
5. Karaosmanoğlu T, Müftüoğlu S, Dağdeviren A, Durgun B, Aygün $\mathrm{B}$, Ors U. Morphological changes in the myenteric plexus of rat ileum after transection and end-to-end anastomosis. J Anat 1996; 188(Pt 2):323-331.

6. Katsui R, Kojima Y, Kuniyasu H, et al. A new possibility for repairing the anal dysfunction by promoting regeneration of the reflex pathways in the enteric nervous system. Am J Physiol Gastrointest Liver Physiol 2008;294:G1084-G1093.

7. Katsui R, Kuniyasu H, Matsuyoshi H, Fujii H, Nakajima Y, Takaki M. The plasticity of the defecation reflex pathway in the enetric nervous system of guinea pigs. J Smooth Muscle Res 2009; 45:1-13.

8. Liu M, Gershon MD. Neuroprotective/trophic effects of 5-HT receptor stimulation on enteric neurons of mice [abstract]. Neurogastroenterol Motil 2006;18:780-781.

9. Matsuyoshi H, Kuniyasu H, Okumura M, et al. A 5-HT 4 -receptor activation-induced neural plasticity enhances in vivo reconstructs of enteric nerve circuit insult. Neurogastroenterol Motil 2010;22:806813, e226.

10. Kawahara I, Kuniyasu H, Matsuyoshi H, et al. Comparison of effects of a selective $5-\mathrm{HT}$ reuptake inhibitor versus a $5-\mathrm{HT}_{4}$ receptor agonist on in vivo neurogenesis at the rectal anastomosis in rats. Am J Physiol Gastrointest Liver Physiol 2012;302:G588-G597.

11. Wood JD. Enteric nervous system neuropathy: repair and restoration. Curr Opin Gastroenterol 2011;27:106-111.

12. Liu MT, Kuan YH, Wang J, Hen R, Gershon MD. 5-HT He- $_{4}$ ceptor-mediated neuroprotection and neurogenesis in the enteric nervous system of adult mice. J Neurosci 2009;29:9683-9699.

13. Gershon MD, Sherman D. Selective demonstration of serotonergic neurons and terminals in electron micrographs: loading with 5,7-dihydroxytryptamine and fixation with $\mathrm{NaMnO}_{4}$. J Histochem Cytochem 1982;30:769-773.

14. Gershon MD, Altman RF. An analysis of the uptake of 5-hydroxytryptamine by the myenteric plexus of the small intestine of the guinea pig. J Pharmacol Exp Ther 1971;179:29-41.

15. Erde SM, Sherman D, Gershon MD. Morphology and serononergic innervation of physiologically identified cells of the guineapig's myenteric plexus. J Neurosci 1985;5:617-633.

16. Wade PR, Chen J, Jaffe B, Kassem IS, Blakely RD, Gershon MD. Localization and function of a 5-HT transporter in crypt epithelia of the gastrointestinal tract. J Neurosci 1996;16:2352-2364.

17. Chen JX, Pan H, Rothman TP, Wade PR, Gershon MD. Guinea pig 5-HT transporter: cloning, expression, distribution, and function in intestinal sensory reception. Am J Physiol 1998;275(3 Pt 1):G433-G448.

18. Meedeniya AC, Brooks SJ, Hennig GW, Costa M. The projections of 5-hydroxy- tryptamine-accumulating neurones in the myenteric plexus of the small intestine of the guinea-pig. Cell Tissue Res 1998;291:375-384.

19. Gershon MD, Tamir H. Release of endogenous 5-hydroxytryptamine from resting and stimulated enteric neurons. Neuroscience 1981;6:2277-2286.

20. Wade PR, Tamir H, Kirchgessner A, Gershon MD. Analysis of the role of 5-HT in the enteric nervous system using anti-idiotopic antibodies to 5-HT receptors. Am J Physiol 1994;266(3 Pt 1): G403-G416. 
21. Takaki M, Mawe GM, Barasch JM, Gershon MD. Physiological responses of guinea-pig myenteric neurons secondary to the release of endogenous serotonin by tryptamine. Neuroscience 1985;16: 223-240.

22. Takaki M, Branchek T, Tamir H, Gershon MD. Specific antagonism of enteric neural serotonin receptors by dipeptides of 5-hydroxytryptophan: evidence that serotonin is a mediator of slow synaptic excitation in the myenteric plexus. J Neurosci 1985;5:17691780.

23. Mawe GM, Branchek TA, Gershon MD. Peripheral neural serotonin receptors: Identification and characterization with specific antagonists and agonists. Proc Natl Acad Sci USA 1986;83:97999803.

24. Gershon MD. Enteric serotonergic neurones ... finally! J Physiol 2009;587(Pt 3):507.

25. Neal KB, Parry LJ, Bornstein JC. Strain-specific genetics, anatomy and function of enteric neural serotonergic pathways in inbred mice. J Physiol 2009;587(Pt 3):567-586.

26. Li Z, Chalazonitis A, Huang YY, et al. Essential roles of enteric neuronal serotonin in gastrointestinal motility and the development/survival of enteric dopaminergic neurons. J Neurosci 2011; 31:8998-9009.

27. Fiorica-Howells E, Maroteaux L, Gershon MD. Serotonin and the $5-\mathrm{HT}_{2 \mathrm{~B}}$ receptor in the development of enteric neurons. J Neurosci 2000;20:294-305.

28. Gershon MD, Liu MT. Serotonin and neuroprotection in functional bowel disorders. Neurogastroenterol Motil 2007;19(suppl 2):19-24.

29. Pham TD, Gershon MD, Rothman TP. Time of origin of neurons in the murine enteric nervous system: sequence in relation to phenotype. J Comp Neurol 1991;314:789-798.

30. Blaugrund E, Pham TD, Tennyson VM, et al. Distinct subpopulations of enteric neuronal progenitors defined by time of development, sympathoadrenal lineage markers and Mash-1-dependence. Development 1996;122:309-320.

31. Chalazonitis A, Pham TD, Li Z, et al. Bone morphogenetic protein regulation of enteric neuronal phenotypic diversity: relationship to timing of cell cycle exit. J Comp Neurol 2008;509:474-492.

32. Gershon MD, Sherman D, Gintzler AR. An ultrastructural analysis of the developing enteric nervous system of the guinea-pig small intestine. J Neurocytol 1981;10:271-296.

33. Hotta R, Pepdjonovic L, Anderson RB, et al. Small-molecule induction of neural crest-like cells derived from human neural progenitors. Stem Cells 2009;27:2896-2905.

34. Takaki M, Nakayama S, Misawa H, Nakagawa T, Kuniyasu H. In vitro formation of enteric neural network structure in a gut-like organ differentiated from mouse embryonic stem cells. Stem Cells 2006;24:1414-1422.

35. Takaki M, Misawa $\mathrm{H}$, Matsuyoshi $\mathrm{H}$, et al. In vitro enhanced differentiation of neural networks in ES gut-like organ from mouse ES cells by a $5-\mathrm{HT}_{4}$-receptor activation. Biochem Biophys Res Commun 2011;406:529-533.

36. Goto K, Kato G, Kawahara I, et al. In vivo imaging of enteric neurogenesis in the deep tissue of mouse small intestine. PLoS ONE 2013;8:e54814.

37. Gershon MD. Developmental determinants of the independence and complexity of the enteric nervous system. Trends Neurosci 2010;33:446-456.

38. Lake JI, Heuckeroth RO. Enteric nervous system development: migration, differentiation, and disease. Am J Physiol Gastrointest Liver Physiol 2013;305:G1-G24.

39. Obermayr F, Hotta R, Enomoto H, Young HM. Development and developmental disorders of the enteric nervous system. Nat Rev Gastroenterol Hepatol 2013;10:43-57.

40. Foong JP, Nguyen TV, Furness JB, Bornstein JC, Young HM. Myenteric neurons of the mouse small intestine undergo significant electrophysiological and morphological changes during postnatal development. J Physiol 2012;590(Pt 10):2375-2390.

41. Burzynski G, Shepherd IT, Enomoto H. Genetic model system studies of the development of the enteric nervous system, gut motility and Hirschsprung's disease. Neurogastroenterol Motil 2009; 21:113-127.

42. Schuchardt A, D'Agati V, Larsson-Blomberg L, Costantini F, Pachnis V. Defects in the kidney and enteric nervous system of mice lacking the tyrosine kinase receptor Ret. Nature 1994;367:380-383.

43. Moore MW, Klein RD, Fariñas I, et al. Renal and neuronal abnormalities in mice lacking GDNF. Nature 1996;382:76-79.

44. Pichel JG, Shen L, Sheng HZ, et al. Defects in enteric innervation and kidney development in mice lacking GDNF. Nature 1996;382: 73-76.

45. Sánchez MP, Silos-Santiago I, Frisén J, He B, Lira SA, Barbacid $\mathrm{M}$. Renal agenesis and the absence of enteric neurons in mice lacking GDNF. Nature 1996;382:70-73.

46. Baynash AG, Hosoda K, Giaid A, et al. Interaction of endothelin-3 with endothelin-B receptor is essential for development of epidermal melanocytes and enteric neurons. Cell 1994;79:1277-1285.

47. Hosoda K, Hammer RE, Richardson JA, et al. Targeted and natural (piebald-lethal) mutations of endothelin-B receptor gene produce megacolon associated with spotted coat color in mice. Cell 1994;79:1267-1276.

48. Gariepy C, Cass DT, Yanagisawa M. Null mutation of endothelin receptor type $\mathrm{B}$ gene in spotting lethal rats causes aganglionic megacolon and white coat color. Proc Natl Acad Sci USA 1996;93:867872.

49. Iwashita T, Kruger GM, Pardal R, Kiel MJ, Morrison SJ Hirschsprung disease is linked to defects in neural crest stem cell function. Science 2003;301:972-976.

50. Kruger GM, Mosher JT, Tsai YH, et al. Temporally distinct requirements for endothelin receptor $\mathrm{B}$ in the generation and migration of gut neural crest stem cells. Neuron 2003;40:917-929.

51. Natarajan D, Grigoriou M, Marcos-Gutierrez CV, Atkins C, Pachnis V. Multipotential progenitors of the mammalian enteric nervous system capable of colonising aganglionic bowel in organ culture. Development 1999;126:157-168.

52. Bondurand N, Natarajan D, Thapar N, Atkins C, Pachnis V. Neuron and glia generating progenitors of the mammalian enteric nervous system isolated from foetal and postnatal gut cultures. Development 2003;130:6387-6400.

53. Kruger GM, Mosher JT, Bixby S, Joseph N, Iwashita T, Morrison SJ. Neural crest stem cells persist in the adult gut but undergo changes in self-renewal, neuronal subtype potential, and factor responsiveness. Neuron 2002;35:657-669. 
54. Mosher JT, Yeager KJ, Kruger GM, et al. Intrinsic differences among spatially distinct neural crest stem cells in terms of migratory properties, fate-determination, and ability to colonize the enteric nervous system. Dev Biol 2007;303:1-15.

55. Liu W, Wu RD, Dong YL, Gao YM. Neuroepithelial stem cells differentiate into neuronal phenotypes and improve intestinal motility recovery after transplantation in the aganglionic colon of the rat. Neurogastroenterol Motil 2007;19:1001-1009.

56. Micci MA, Kahrig KM, Simmons RS, Sarna SK, Espejo-Navarro MR, Pasricha PJ. Neural stem cell transplantation in the stomach rescues gastric function in neuronal nitric oxide synthase-deficient mice. Gastroenterology 2005;129:1817-1824.

57. Lindley RM, Hawcutt DB, Connell MG, et al. Human and mouse enteric nervous system neurosphere transplants regulate the function of aganglionic embryonic distal colon. Gastroenterology 2008; 135:205-216.

58. Yamada T, Yoshikawa M, Takaki M, et al. In vitro functional gut-like organ formation from mouse embryonic stem cells. Stem Cells 2002;20:41-49.

59. Wu JJ, Chen JX, Rothman TP, Gershon MD. Inhibition of in vitro enteric neuronal development by endothelin-3: mediation by endothelin B receptors. Development 1999;126:1161-1173.

60. Baeyens R, Reyntjens A, Verlinden M. Cisapride accelerates gastric emptying and mouth-to-caecum transit of a barium meal. Eur J Clin Pharmacol 1984;27:315-318.

61. Mawe GM, Hoffman JM. Serotonin signalling in the gut-functions, dysfunctions and therapeutic targets. Nat Rev Gastroenterol Hepatol 2013;10:473-486.

62. Mazzia C, Hicks GA, Clerc N. Neuronal location of 5-hydroxytryptamine 3 receptor-like immunoreactivity in the rat colon. Neuroscience 2003;116:1033-1041.

63. Bertrand PP, Kunze WA, Furness JB, Bornstein JC. The terminals of myenteric intrinsic primary afferent neurons of the guinea-pig ileum are excited by 5-hydroxytryptamine acting at 5-hydroxytryptamine-3 receptors. Neuroscience 2000;101:459-469.

64. Andresen V, Montori VM, Keller J, West CP, Layer P, Camilleri M. Effects of 5-hydroxytryptamine (serotonin) type 3 antagonists on symptom relief and constipation in nonconstipated irritable bowel syndrome: a systematic review and meta-analysis of randomized controlled trials. Clin Gastroenterol Hepatol 2008;6:545-555.

65. Rahimi R, Nikfar S, Abdollahi M. Efficacy and tolerability of alosetron for the treatment of irritable bowel syndrome in women and men: a meta-analysis of eight randomized, placebo-controlled, 12week trials. Clin Ther 2008;30:884-901.

66. Galligan JJ, LePard KJ, Schneider DA, Zhou X. Multiple mechanisms of fast excitatory synaptic transmission in the enteric nervous system. J Auton Nerv Syst 2000;81:97-103.

67. Tong W, Kamiyama Y, Ridolfi TJ, et al. The role of $5-\mathrm{HT}_{3}$ and $5-\mathrm{HT}_{4}$ receptors in the adaptive mechanism of colonic transit following the parasympathetic denervation in rats. J Surg Res 2011; 171:510-516.

68. Liu MT, Rayport S, Jiang Y, Murphy DL, Gershon MD. Expression and function of $5-\mathrm{HT}_{3}$ receptors in the enteric neurons of mice lacking the serotonin transporter. Am J Physiol Gastrointest Liver Physiol 2002;283:G1398-G1411.

69. Brattelid T, Kvingedal AM, Krobert KA, et al. Cloning, pharmaco- logical characterisation and tissue distribution of a novel $5-\mathrm{HT}_{4}$ receptor splice variant, 5- $\mathrm{HT}_{4(\mathrm{i})}$. Naunyn-Schmiedeberg's Archiv Pharmacol 2004;369:616-628.

70. Bender E, Pindon A, van Oers I, et al. Structure of the human serotonin $5-\mathrm{HT}_{4}$ receptor gene and cloning of a novel $5-\mathrm{HT}_{4}$ splice variant. J Neurochem 2000;74:478-489.

71. McCallum RW, Prakash C, Campoli-Richards DM, Goa KL. Cisapride. A preliminary review of its pharmacodynamic and pharmacokinetic properties, and therapeutic use as a prokinetic agent in gastrointestinal motility disorders. Drugs 1988;36:652-681.

72. Degen L, Petrig C, Studer D, Schroller S, Beglinger C. Effect of tegaserod on gut transit in male and female subjects. Neurogastroenterol Motil 2005;17:821-826.

73. Evans BW, Clark WK, Moore DJ, Whorwell PJ. Tegaserod for the treatment of irritable bowel syndrome and chronic constipation. Cochrane Database Syst Rev 2008;(4):CD003960.

74. Liu Z, Sakakibara R, Odaka T, et al. Mosapride citrate, a novel $5-\mathrm{HT}_{4}$ agonist and partial $5-\mathrm{HT}_{3}$ antagonist, ameliorates constipation in parkinsonian patients. Mov Disord 2005;20:680-686.

75. Bischoff SC, Mailer R, Pabst $\mathrm{O}$, et al. Role of serotonin in intestinal inflammation: knockout of serotonin reuptaketransporter exacerbates 2,4,6-trinitrobenzene sulfonic acid colitis in mice. Am J Physiol Gastrointest Liver Physiol 2009;296:G685-G695.

76. Fujisawa M, Murata T, Hori M, Ozaki $\mathrm{H}$. The $5-\mathrm{HT}_{4}$ receptor agonist mosapride attenuates NSAID-induced gastric mucosal damage. J Gastroenterol 2010;45:179-186.

77. Tsuchida Y, Hatao F, Fujisawa M, et al. Neuronal stimulation with 5-hydroxytryptamine 4 receptor induces anti-inflammatory actions via alpha7nACh receptors on muscularis macrophages associated with postoperative ileus. Gut 2011;60:638-647.

78. Hanani M, Ledder O, Yutkin V, et al. Regeneration of myenteric plexus in the mouse colon after experimental denervation with benzalkonium chloride. J Comp Neurol 2003;462:315-327.

79. Willaime-Morawek S, Seaberg RM, Batista C, et al. Embryonic cortical neural stem cells migrate ventrally and persist as postnatal striatal stem cells. J Cell Biol 2006;175:159-168.

80. Nishimura M, Koda K, Oda K, et al. Decreased interstitial cells of Cajal in the neorectum after anterior resection of the rectum. Hepatogastroenterology 2006;53:665-668.

81. Terauchi A, Kobayashi D, Mashimo H. Distinct roles of nitric oxide synthases and interstitial cells of Cajal in rectoanal relaxation. Am J Physiol Gastrointest Liver Physiol 2005;289:G291-G299.

82. Yanagida H, Yanase H, Sander KM, Ward SM. Intestinal surgical resection disrupts electrical rhythmicity, neural responses, and interstitial cell networks. Gastroenterology 2004;127:1748-1759.

83. Mei F, Yu B, Ma H, Zhang HJ, Zhou DS. Interstitial cells of Cajal could regenerate and restore their normal distribution after disrupted by intestinal transection and anastomosis in the adult guinea pigs. Virchows Arch 2006;449:348-357.

84. Faussone-Pellegrini MS, Vannucchi MG, Ledder O, Huang TY, Hanani M. Plasticity of interstitial cells of Cajal: a study of mouse colon. Cell Tissue Res 2006;325:211-217.

85. O'Riordain MG, Molloy RG, Gillen P, Horgan A, Kirwan WO. Rectoanal inhibitory reflex following low stapled anterior resection of the rectum. Dis Colon Rectum 1992;35:874-878.

86. Williamson ME, Lewis WG, Finan PJ, Miller AS, Holdsworth 
PJ, Johnston D. Recovery of physiologic and clinical function after low anterior resection of the rectum for carcinoma: myth or reality? Dis Colon Rectum 1995;38:411-418.

87. Nagoshi N, Shibata S, Kubota Y, et al. Ontogeny and multipotency of neural crest-derived stem cells in mouse bone marrow, dorsal root ganglia, and whisker pad. Cell Stem Cell 2008;2:392-403.

88. Mattson MP, Maudsley S, Martin B. BDNF and 5-HT: a dynamic duo in age-related neuronal plasticity and neurodegenerative disorders. Trends Neurosci 2004;27:589-594.

89. Cazorla M, Prémont J, Mann A, Girard N, Kellendonk C, Rognan D. Identification of a low-molecular weight $\operatorname{TrkB}$ antagonist with anxiolytic and antidepressant activity in mice. J Clin Invest 2011; 121:1846-1857.

90. Ishikawa T, Nakayama S, Nakagawa T, et al. Characterization of in vitro gutlike organ formed from mouse embryonic stem cells. Am J Physiol Cell Physiol 2004;286:C1344-C1352.

91. Kusakawa S, Nakamura K, Miyamoto Y, et al. Fluoxetine promotes gliogenesis during neural differentiation in mouse embryonic stem cells. J Neurosci Res 2010;88:3479-3487.

92. Malberg JE, Eisch AJ, Nestler EJ, Duman RS. Chronic antidepressant treatment increases neurogenesis in adult rat hippocampus. J Neurosci 2000;20:9104-9110.

93. Kobayashi K, Ikeda Y, Sakai A, et al. Reversal of hippocampal neuronal maturation by serotonergic antidepressants. Proc Natl Acad Sci USA 2010;107:8434-8439.

94. Kobayashi K, Ikeda Y, Haneda E, Suzuki H. Chronic fluoxetine bidirectionally modulates potentiating effects of serotonin on the hippocampal mossy fiber synaptic transmission. J Neurosci 2008; 28:6272-6280.

95. Enomoto H, Hughes I, Golden J, et al. GFRalpha1 expression in cells lacking RET is dispensable for organogenesis and nerve regeneration. Neuron 2004;44:623-636.

96. Uesaka T, Jain S, Yonemura S, Uchiyama Y, Milbrandt J, Enomoto $\mathrm{H}$. Conditional ablation of GFRalpha1 in postmigratory enteric neurons triggers unconventional neuronal death in the colon and causes a Hirschsprung's disease phenotype. Development 2007; 134:2171-2181.

97. Uesaka T, Nagashimada M, Yonemura S, Enomoto H. Diminished Ret expression compromises neuronal survival in the colon and causes intestinal aganglionosis in mice. J Clin Invest 2008;118:1890-1898.

98. Shah BH, Catt KJ. GPCR-mediated transactivation of RTKs in the CNS: mechanisms and consequences. Trends Neurosci 2004;27: 48-53.

99. Ohya TR, Sumiyama K, Takahashi-Fujigasaki J, Dobashi A, Saito $\mathrm{S}$, Tajiri H. In vivo histologic imaging of the muscularis propria and myenteric neurons with probe-based confocal laser endomicroscopy in porcine models (with videos). Gastrointest Endosc 2012;75:405410 .

100. Fernandes KJ, Kobayashi N, Gallagher CJ, et al. Analysis of the neurogenic potential of multipotent skin-derived precursors. Exp Neurol 2006;201:32-48.

101. Arthur A, Rychkov G, Shi S, Koblar SA, Gronthos S. Adult human dental pulp stem cells differentiate toward functionally active neurons under appropriate environmental cues. Stem Cells 2008;26: 1787-1795.

102. Takahashi K, Tanabe K, Ohnuki M, et al. Induction of pluripotent stem cells from adult human fibroblasts by defined factors. Cell 2007;131:861-872.

103. Nishikawa S, Goldsten RA, Nierras CR. The promise of human induced pluripotent stem cells for research and therapy. Nat Rev Mol Cell Biol 2008;9:725-729. 